Kohl: a Journal for Body and Gender Research

Vol. 1, No. 2 (Winter 2015)

\title{
Curse Words: The Language of (Hetero)Intimacy
}

\author{
Cynthia El Khoury
}


Languages evolve. They are ever changing and adapt to the varying needs of societies. It is only natural to question those needs and the balance of power behind them, especially when illnesses such as "hysteria" and conditions like "Premenstrual Syndrome" (PMS) are still used against women in our world. Hysteria is a word which derives from the Greek translation of "uterus" to indicate mental illness caused by disturbances of the organ. PMS is a medical and cultural construct created to pathologize women's cyclic experiences. Hyster, the womb, thus became a source of ills and mental disturbances. Across languages, women and their organs are used in derogatory curse words as a mean to shame and degrade others. Vagina, for instance, is a symbol for female submission or cowardice. On the other hand, men and their bits are equated to power, control, and dominance. Testicles, for example, signify masculinity and strength ("grow some balls" or "man up"). Languages evolve to serve those who are lawfully powerful and deem others powerless. The patriarch use women to swear, fragmenting and dismantling their whole into passive bits. In Beirut, "cunt" is moving from being a word that conveys a negative emotion into one that denounces fear and horror. Has the once utilized and passively cursed cunt come alive to become a canal for denouncement of fear? And are voices of dissent using the master's tools, or are they dismantling his house 1 instead?

\section{Sex, slangs, and slurs}

According to Steven Pinker, death and infirmity constitute one of the five categories of swear words ${ }^{2}$ that most people use to convey a certain emotion. El aama bi albak, ${ }^{3}$ I once hurled at my brother, in a moment filled with rage. My mother, who overheard us bickering, asked me if I was aware of the meaning of those words. I was 7 at the time, and so, I fragmented the sentence like every questioning child would, only to realize that I had wished for my brother's heart to go blind, i.e. to stop functioning. Blinding someone's heart is a synonym for death, but "that was not what I meant," as I explained in remorse and guilt to my mother. The imagery behind my own words was full of violence and bad-ill. It did not reflect what I wanted to express to my sibling. The effects of this incident stuck with me, and my brain neurons wired themselves as to never to wish for any organ of my brother to shut down. I had learned the power of words and intentions.

Beirut, September 15, 2015. A social justice activist in Lebanon calls his feminist Facebook friends to join him in celebrating what looked like to be a sign of a longed for revolution: his 6-year-old neighbor's curse words. La kossi abou kees, ${ }^{4}$ answered back a little girl to her screaming father who was asking her to go to bed. Pinker suggests that we also use sex (genitalia terminology being one of them) to convey "negative emotion." Taboo words mainly express all that which we - do not want to - feel, such as disgust, anger, frustration, and fear. The father of the cursing child might have sensed that he was losing some authority over his daughter. He considered that the only way for him to get her to go to bed was by threatening her to call a spookier entity: the boogieman Abou Kees. Clearly, the girl was neither intimidated by her father nor

\footnotetext{
${ }^{1}$ Audre Lorde, "The Master's Tools Will Never Dismantle the Master's House."

2 Pinker. S. (2007). The Stuff of Thought: Language as a Window into Human Nature. New York, NY: Viking.

3 "May your heart go blind" in Arabic

4 "To my cunt, the boogieman," or "the boogieman is worth my cunt" in Arabic. Used to express indifference.
} 
by his patriarchal stand. Neither had any valid reason to get her to do anything else than what she was doing at that precise moment in time. She had screamed resistance through her body, literally. Her resisting orders shocked the patriarchal system in her rejection of her father's orders and his alter ego, but she unknowingly gathered supporters on her neighbor's Facebook page. Most strikingly, she had somehow replaced the preferred genitalia swear word "la ayree" (to my penis) with its "female" equivalent - "ayree" being your most popular curse word to convey indifference, lack of intimidation and fearfulness. When pressed to explain what she meant, the young rebel was heard questioning with spleen her brother's "right to shove his penis in everything." Not only did she invent a new way to swear, but she also called on her genital powers in an unfamiliar act of resistance. Has "the boogie man is worth my vagina" become another way to express resistance through indifference? In other words, is the word "cunt" another form to trivialize a situation, or is it sometimes used to delineate resistance in accordance with the context? Or has cunt become so powerful that it too had the right to assert power?

"Al-koss"5 or "koss" is the Arabic slang for vagina and the equivalent of the English word, cunt. It is believed to derive from the Turkish translation of the word "girl" - kIz ${ }^{6}$ - with the origins of the word dating back to the times when the Ottomans ruled over the Arab region.

So how did exactly girl get translated into vagina? As I am not an expert in history or linguistics, and because the traditional disciplines of history and linguistics are mostly patriarchal endeavors, I resort to the power of imagination to recollect what might have been left out from empirical terms and history books. Now, let us all imagine Beirut and the region at the times of the Ottoman Empire: we would witness merchants and soldiers moving across Sukleen-free lands. Not only would they be asking for food and shelter, but they would also be demanding sex. Now, imagine those men requesting a kız at a brothel, turning a whole woman into a specific hole of her body. ${ }^{7}$ This paved the way for koss to be transformed into a curse word, used mainly by men in moments of anger and exhibition of power over other men and women. ${ }^{8}$ We are all familiar with the exquisitely drawn images of people shoving their penises in other people's sister or mother's vagina. What is supposed to give and receive pleasure and life is abstracted and attacked by the power of words. More, it is turned into a way to channel anger and assert dominance. When the koss becomes a public playground for undesired emotions, the vagina "canal" passively delivers violence and aggression instead of giving pleasure and life to its rightful owner.

So what did the little girl mean when she used koss to express herself? Was she feeling ${ }^{9}$ the power of her organ, or was she simply replicating the system's curse words with a gendered twist?

\footnotetext{
${ }^{5}$ See: http://www.almaany.com/ar/dict/ar-ar/\%D8\%A7\%D9\%84\%D9\%83\%D8\%B3/

${ }^{6} \mathrm{lbid}$.

${ }^{7}$ Another common economic transaction controlled by Ottoman-rule was that of "tuz." Tuz translates to "salt" in English and to "fart" in Arabic, but it evolved into a modern Arabic slang word used nowadays across the region to convey indifference. Just like koss, tuz became another commodity available upon demand by those who could afford to buy it.

${ }^{8}$ For instance, koss ommak (your mother's cunt) and koss okhtak (your sister's cunt) are widely used.

${ }^{9}$ Audre Lorde, "The Uses of the Erotic: The Erotic as Power."
} 


\section{My Koss, My Resource}

[vah-ji'nah] (pl. vagi'nae) ${ }^{10}$

1. any sheath or sheathlike structure.

2. the canal in the female that extends from the external genitalia to the cervix uteri. The adult vagina is normally about $8 \mathrm{~cm}(3 \mathrm{in})$ long and slopes upward and backward. Internally, the bladder is in front of the vagina and the rectum in back. The vagina receives the erect penis in coitus; spermatozoa are discharged into it, swim through the cervical canal, and enter the uterus. The vagina is also the passage for menstrual discharge, and it functions as the birth canal.

So what exactly do we think of when we hear the word vagina? I frequently asked this question at the sexual health trainings that I gave over the past years; the sequencing of answers resonated among the different groups of participants. People from different age groups, educational levels, sociological and economic backgrounds all agreed that it is first associated with "birth," a reproductive-made organ attached to the body of a gendered female who, at times, dares to use that space for her own source of pleasure. They would only mention pleasure when I insisted for other connotations. "Society has complete control over it," 11 states one set of lips in a video that narrates perceptions of women's vaginas. Others spoke of how their mothers shaped their experiences with their vaginas. Some sighed while others licked their lips.

Listening to the answers of the participants always bring my own experiences and memories to the surface. I was six when my mother told me not to open my legs while we sat at the doctor's waiting room. When I asked her why the boy in front of me was sitting that way, she simply answered that since he is a boy, he can. The way he sits would not get interpreted as a call for violation. If heterosexist societies could blatantly write their own definition of their vagina, or simply read between the lines of empirical dictionaries, it would go as follows:

3. Vagina: feminine, dirty, stinky, untidy, too small, too big, too hairy, too loose, too tight, hetero, reproductive, virgin, hymen, hysteric, a cavity for the penis, a word borrowed from individuals and used by individuals to convey power, violence and oppression, needs protection, controlled by men and governed by laws. The cradle of mental illnesses and uncontrolled feelings and emotions.

In his piece "the Great Wall of Vagina" artist Jamie McCartney invites us, peoples with vaginas, to change our perception of ourselves by exposing the anatomical diversity of vulvas and labia. While McCartney's work visited many galleries, another artist's 3-D print of her vagina caused her trouble with the law for making vagina art. ${ }^{12}$ The emancipation of the vagina is yet again delivered by a man who is here to alleviate women from their anxieties.

\footnotetext{
10 See: http://medical-dictionary.thefreedictionary.com/vagina

${ }^{11}$ Check Marsa Sexual Helath Center's video for IWD 2014: https://www.youtube.com/watch?v=UAEAZ MiEmQ

12 Japanese artist Megumi Igarashi faced obscenity charges after sailing a 3-D printed vagina-shaped kayak.
} 
This resonates with some men's excuse for resorting to anal sex as opposed to vaginal sex. "[she said she wants to, but she's still a virgin and] I don't want to hurt her." It is a common response when they are asked about the type of sex that they engage in. But who was it really that the men did not want to hurt? ${ }^{13}$ Virginity and its tests are positioned within logics of honor ${ }^{14}$ to shame and dominate women's sexuality, and to protect men's economic power and honor. Our "precious" hymens become the matter of inspection by the male doctor ${ }^{15}$ who examines, takes notes, and reports to the authorities on the matter. Under Lebanese law, they are considered indicators of whether a woman is a sex worker or if a man stands a chance at a marriage annulment - a legal tradition that was passed on to us from the times of the Assyrians, who transmitted it to the Jews, Christians, and Muslims of the region. ${ }^{16}$ Unlike anal tests that target homosexual men, the practice of virginity tests is widely underdocumented. It is also used as a threat to intimidate and silence women, another practice that gets little to no attention from human rights activists.

The discipline of medicine, through its artistic media (anatomy), attempted to prove that women are worth less than men. ${ }^{17}$ Women were hailed as healers, but were banned from entering medical school ${ }^{18}$ and judged unable to testify against the courts of law in certain contexts. Our anatomy was represented by men who dominated anatomical theaters and classrooms, as well as by the male artists who were invited to transform lectures into canvases. Anatomy is socially constructed and politically represented, as women are gendered through its biological language. The way we create words and their meanings, such as vagina vs. penis, is dominated by a polarized world, where men's bodies are the powerful norm, while women's are perceived as deviant and weak. We understand our bodies through our mother tongues and other languages that we acquire with time. We transpose this understanding to artistic representations of the anatomy in general, and of the vagina in particular, and we connect to those representations and embody them. But some women are sick of having their bodies fragmented and their most erotic and intimate part used to convey power and violence. Expressions such as koss okhtak or baddi neek koss ommak ${ }^{19}$ are commonly uttered to convey anger and to assert dominance and power. "Kossi mish msabbi," or "my cunt is not a curse word," can be seen stenciled on the walls of the streets of Beirut in an attempt to take back the word by their rightful owners. This was the first time that koss echoed through the walls of Beirut in a possessive pronoun. Was it sisters, or mothers, or both who stenciled this piece on the walls? I don't know; but what I am certain of is that some body was claiming back ownership over every bit of themselves.

"Cunt," a word that once indicated cowardice, is stating that it wants to be left alone.

\footnotetext{
${ }^{13}$ Men who trick a girl with promises of marriage and break a virgin's hymen can be imprisoned up to six months and pay a fine of 200,000 Lebanese liras. See: http://www.jadaliyya.com/pages/index/376/a-legal-guide-to-being-alebanese-woman-(part-1)

${ }_{14}$ See: http://www.jadaliyya.com/pages/index/2598/honoring-the-law_honor-gender-and-crime-in-the-leb

15 Note that this was commonly practiced by women / nuns / queens to test their level of guilt.

${ }^{16}$ Erick Berkowitz, E. (2012). Sex and Punishment: Four Thousand Years of Judging Desire. Berkeley: Counterpoint. 17 When scientists compared the male brain to the female brain, they suggested that women's brains were lighter than men's. "Women have half-brains" is a common saying in Arabic.

18 Ehrenreich, B., \& English, D. (2010). Witches, Midwives, and Nurses: A History of Women Healers. New York City: The Feminist Press.

19 "Your sister's cunt" or "I want to fuck your mother's cunt."
} 